\title{
Sheep Spatial Grazing Strategies at the Arid Patagonian Monte, Argentina
}

\author{
Mónica B. Bertiller and Jorge O. Ares \\ Authors are Scientific Researchers, Centro Nacional Patagónico-CONICET, and Professors, Universidad Nacional de la Patagonia-UNPSJB, \\ 9120 Puerto Madryn, Chubut, Argentina.
}

\begin{abstract}
We asked what vegetation traits influence sheep in selecting foraging paths on the range. We obtained 40000 records of positions of six ewes (Ovis aries) collared with Global Positioning System receivers during several seasons in a paddock of 1250 ha at the Patagonian Monte shrublands, Argentina. We classified the vegetation through ground-truth floristic analyses and remotely sensed imagery, and overlaid the ewes' positions onto a digital map of vegetation units. For each vegetation unit, we assessed the cover of main life forms and preferred plants, the visibility range at ewe's head height, and several structural/chemical traits of dominant shrubs (leaf mass/area, lignin-phenolics-nitrogen concentration in leaves, presence of thorny stems and spiny leaves). Ewes followed diverse paths across the paddock but always selected among a limited number of vegetation units. Selected vegetation units were those with structural traits allowing wide ewes' visibility ranges and low structural antiherbivore defenses, irrespective of their local abundance, relative cover of preferred plants, or distance to the watering point. Within preferred vegetation units, ewes further selected those with high cover of preferred plants and/or reduced structural/chemical antiherbivore defenses. We concluded that sheep selectivity at our study paddock resulted from compromises among different structural/visual cues related to visual impairment, antiherbivore physical/chemical defenses, and the offer of preferred plants. In a hierarchy of decisions, the abundance of preferred plants was not a sufficient condition for a high selection of vegetation units. Monitoring animal movements within shrubby paddocks of the Patagonian Monte with high visual impairment can supply criteria to assess the relevance of nonnutritional environmental traits on grazers' decisions. This information is valuable in identifying and predicting spots of potential land degradation, and planning the distribution of flocks within paddocks in the context of sustainable management practices for shrubby rangelands.
\end{abstract}

\begin{abstract}
Resumen
Nos preguntamos que atributos de la vegetación influencian la selectividad de los ovinos respecto de diferentes unidades de vegetación a lo largo de sus caminos de pastoreo. Obtuvimos 40000 registros de posiciones de seis ovejas (Ovis aries) equipadas con collares con receptores de sistemas de posicionamiento global, durante varias estaciones en un potrero de 1250 ha en los arbustales del Monte patagónico de Argentina. Clasificamos la vegetación a través de análisis de muestreos florísticos de campo y de imágenes de sensores remotos y superpusimos las posiciones de las ovejas en un mapa digital de unidades de vegetación. Para cada unidad de vegetación, estimamos la cobertura de las principales formas de vida y de las plantas preferidas por los ovinos, el rango de visibilidad horizontal a la altura de la cabeza de las ovejas y varios atributos estructurales y químicos de los arbustos dominantes (masa/área de hoja, concentración de lignina, compuestos fenólicos y nitrógeno en las hojas, presencia de tallos con espinas leñosas y hojas espinosas). Las ovejas usaron diversos caminos de pastoreo a lo largo del potrero pero siempre seleccionaron un número limitado de unidades de vegetación. Las unidades de vegetación seleccionadas fueron aquellas con atributos estructurales que les permitieron un amplio rango de visibilidad y que presentaban bajas defensas estructurales antiherbívoro, independientemente de la abundancia local de plantas preferidas y de la distancia a la aguada. Dentro de estas unidades, las ovejas seleccionaron aquellos parches que ofrecieron alta cobertura de plantas preferidas y/o reducidas defensas estructurales/ químicas antiherbívoro. Concluimos que la selectividad de las ovejas dentro de nuestro potrero de estudio resultó de un compromiso entre diferentes atributos que involucran indicadores estructurales/visuales relacionados con la obstaculización visual, defensas antiherbívoro físicas y químicas, y la oferta de plantas preferidas. En un orden jerárquico de decisiones, la abundancia de plantas preferidas no fue una condición suficiente para una alta selección de las unidades de vegetación. El seguimiento de los movimientos de los animales dentro de los arbustales del Monte patagónico con alta obstaculización visual podría proveer criterios para evaluar la relevancia de atributos ambientales no nutricionales sobre las decisiones de los herbívoros. Esta información es relevante para predecir focos de degradación potencial y planificar la distribución de las majadas en los potreros dentro de un marco de prácticas de manejo sustentables para las áreas de pastoreo arbustivas.
\end{abstract}

Key Words: arid shrublands, grazing behavior, grazing tactics, patch selection, visibility

\section{INTRODUCTION}

Research was funded by the Agency for Scientific and Technological Promotion of Argentina (PICT 08-6027, 08-20454-BID 802/1201/1728 OC-AR-FONCYT-ANPCyT) and the National Council for Scientific Research of Argentina (PIP 6496-CONICET).

Correspondence: Mónica B. Bertiller, Centro Nacional Patagónico-CONICET, Boulevard Brown 2825, 9120 Puerto Madryn, Chubut, Argentina. Email: bertil@cenpat.edu.ar

Manuscript received 22 March 2007; manuscript accepted 5 September 2007.
Identifying the rules of decision that herbivores use while foraging in different environments is of relevance to test ecological hypothesis related to plant-animal interactions at different scales (Judson 1994; WallisDeVries et al. 1999; Searle et al. 2006). It is also important in understanding landscape use patterns of livestock and planning for sustainable rangeland use 
(Launchbaugh and Howery 2005; Bailey et al. 2006). Key questions about grazing search mechanisms involve the cues used by grazers at different spatial scales to select grazing locations and preferred plants within them, continuing the use of a selected vegetation patch or moving to a neighbor one (Senft et al. 1987; Bailey et al. 1996; Wallis DeVries et al. 1999; Fortin et al. 2003; Oom et al. 2004).

Senft et al. (1987) recognized two steps in the selection of feeding patches. The "location selection" step implies how herbivores move through plant communities. The "diet selection" step refers to which plants or parts of plants herbivores select to consume. Many studies assumed that grazers encounter food patches in proportion to their abundance, forage biomass, and the distance to a previous selected neighbor patch. According to these, searching would be a simple systematic or random process (Noy-Meir 1973; Charnov 1976; Owen-Smith and Novellie 1982; Stephens and Krebs 1986; Fryxell and Doucet 1993; Fortin et al. 2002; Oom et al. 2004; Searle et al. 2006). Other studies emphasized that search tactics are cognitive processes, or decision sequences that organisms use to locate available resources such as food, mates, refuges, or high-quality habitats (Viswanathan et al. 1999; Zollner and Lima 1999). The location of the watering point or places with drinkable free water has also been repeatedly indicated as major factors influencing the distribution and spatial foraging strategies of free-ranging herbivores (Graetz and Ludwig 1978; Jeltsch et al. 1997; Adler and Hall 2005). There is also evidence that nonnutritional factors such as habitat intricacy and visibility could influence foraging behavior of herbivores at large spatial scales (Fortin 2002; Fortin et al. 2003). Visual scanning in free-grazing large herbivores seems to be relevant for orientation, search, vigilance, and asserting the size of the surrounding kin group. Ungulates living in open habitat form groups, and individuals decrease vigilance and increase bite rate with increasing group size (Jarman 1974; Berger 1978; Risenhoover and Bailey 1985; Penning et al. 1993; Molvar and Bowyer 1994; Barta et al. 2004). Visual contact might be also relevant in maintaining the stability of unherded sheep groups when crossing their trajectories without mixing (Brown 1970).

In arid shrublands, large herbivores must find their preferred food patches while negotiating plant structures of heights nearly at or above their horizontal visual range and with strong chemical and physical defenses (Lauenroth 1998; Adler et al. 2005). How the intricacy of shrubland vegetation affects horizontal visibility of herbivores and their grazing decisions and how antiherbivore defenses influence local grazing choices are issues scarcely explored in arid shrubby ecosystems of the world grazed by free-ranging large herbivores. Monitoring the spatial location of grazing animals in relation to vegetation traits could contribute to identifying rules related to animal decisions about the selection of feeding areas and the permanence on them in shrublands (Skarpe et al. 2007). This information is relevant to plan the distribution of herds within paddocks, avoiding spots of land degradation in a context of adaptive management planning (Ganskopp and Bohnert 2006; Morghan et al. 2006).

We hypothesized that sheep selectivity at shrubby rangelands of the Patagonian Monte results from compromises among different currencies involving structural/visual cues related to visual impairment, antiherbivore physical/chemical defenses, and the offer of preferred plants. We predicted that 1) floristicphysiognomic vegetation units with different visibility range, chemical/structural antiherbivore defenses, and cover of preferred plants can be identified within large paddocks and at paddock subareas differing in their distance to the watering point; 2) sheep could perceive vegetation heterogeneity within the paddock by differentially selecting vegetation units with high visibility range (structural/visual cues); and 3) within vegetation units with high visibility, sheep would further select those with high (although eventually not maximum) forage quality and low antiherbivore defenses.

\section{METHODS}

\section{Study Site}

The study site is at an extended flat area dominated by the xeromorphic tall shrub community of jarilla (Larrea divaricata Cav.) and coirones (Stipa spp.), characteristic of the Patagonian Monte (Ares et al. 1990; León et al. 1998). Perennial plants (mostly shrubs) contribute to more than $99 \%$ of the total biomass and form patches covering from $40 \%$ to $60 \%$ of the soil. The area is arranged in large paddocks (1 000 to $2500 \mathrm{ha}$ ) and has been grazed by unherded sheep since the beginning of the 20th century. Annual grasses, forbs, and perennial grasses are the main preferred plant life forms of sheep (Baldi et al. 2004). Wells to supply water to the foraging animals are usually located at a single corner of the paddocks. Extended piospheres (more than $2500 \mathrm{~m}$ ) are generated around watering points where structural characteristics of the plant communities are modified by frequent visits of the grazing animals (Ares et al. 2003; Bisigato et al. 2005). Within the area, we selected a triangular paddock of about 1250 ha at Smit's Ranch (lat $42^{\circ} 38^{\prime} \mathrm{S}$, long $65^{\circ} 23^{\prime} \mathrm{W}$ ) with a single watering point at its northeastern corner. The paddock was submitted to the usual stocking rate for the area (approximately 0.10 sheep $\cdot \mathrm{ha}^{-1}$ )

\section{Characterization of the Heterogeneity of Vegetation Within the Paddock (Prediction 1)}

Vegetation Units and Patchiness. We identified and described floristic-physiognomic vegetation units (VUs) within the paddock through the combination of ground-truth floristic sampling and analyses of remote imagery using the program IDRISI (v14.02; Clark Labs, Worcester, MA). We performed a preliminary identification of VUs within the paddock through an unsupervised classification procedure performed on all eight bands of a Landsat-7 image of the area obtained in September 2002, geo-referenced with conspicuous ground-truth points. The classification resulted from an iterative cluster analysis using a multivariate histogram peak technique (Richards 1986). We controlled the mapped VU boundaries in the field through ground checks (October-November 2005) and characterized the floristic composition of each VU by registering the species plant cover at 25 randomly selected sampling sites of about $10000 \mathrm{~m}^{2}$ each (three to six sites per VU, depending on VU areas). Plant cover was visually estimated using cover categories with increments of $1 \%$ (Bisigato and Bertiller 


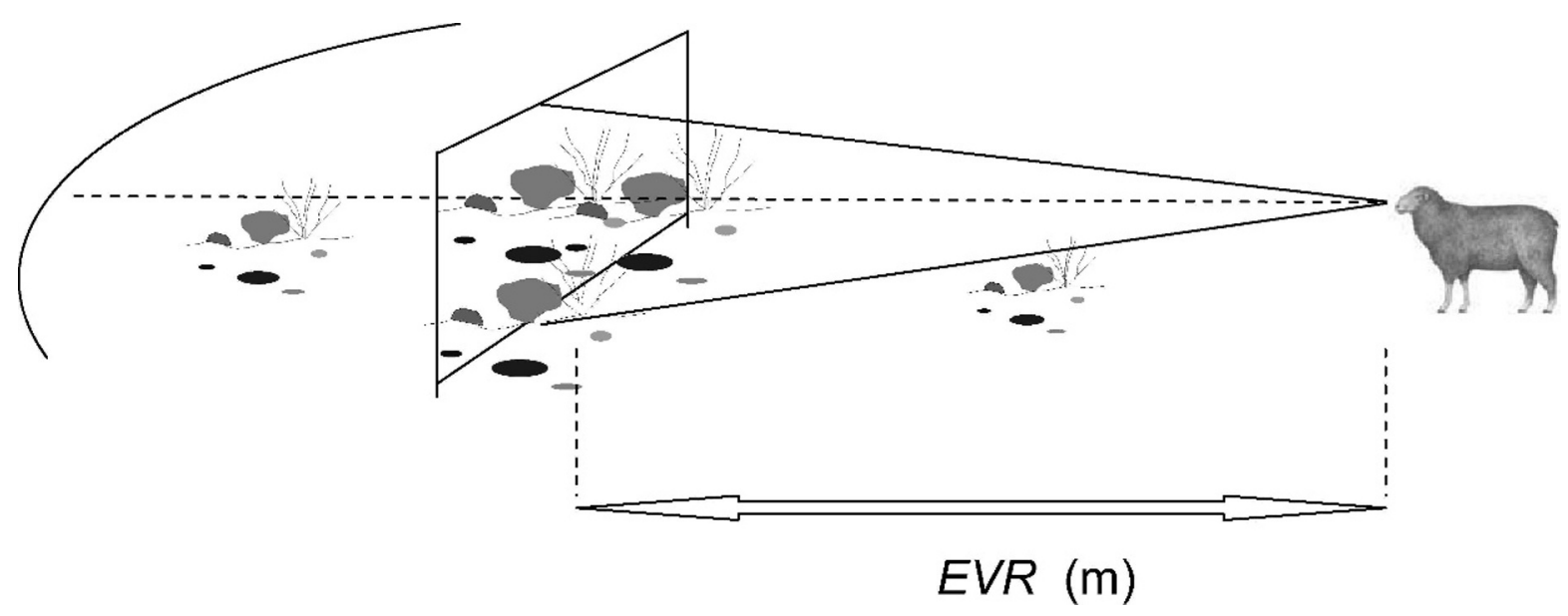

Figure 1. Operational definition of ewes' visibility range (EVR). The focal plane corresponds to that of an optical telemeter where vegetation obstructs $50 \%$ of the sight field along a horizontal view at a standing ewe's head height.

1997). Species found at each site were assigned to one of five life forms: tall shrubs (more than $1 \mathrm{~m}$ height), small shrubs (less than $1 \mathrm{~m}$ height, including medium and dwarf shrubs), perennial grasses, perennial forbs, and annuals. We calculated the cover of preferred plants as the sum of the cover of preferred species (perennial and annual grasses and forbs, as well as some species of small and tall shrubs as in Somlo 1997). Further, we computed the total, per life form, and preferred mean plant cover at each VU.

We calculated the relative frequency of each VU both at the whole paddock and at three subareas according to their distance to the watering point: near $(0$ to $2500 \mathrm{~m})$, mid $(2500$ to $4500 \mathrm{~m})$, and far $(>4500 \mathrm{~m})$. We also estimated the area of all patches of each VU at each subarea (IDRISI v14.02; Clark Labs) and calculated their nominal radius (radius of a circle of the same area as the patch). We further calculated the percentage of patches with nominal radius lower than the maximum mean visibility range (see below under Ewes' Visibility Range (EVR) at VUs).

Structural and Chemical Characterization of the Shrubby Cover of VUs. We identified and characterized structural and chemical plant/leaf traits of the dominant shrubby components of VUs related to potential herbivore preference or antiherbivore defenses. Selected (cover) dominant tall shrubs were Boungainvillea spinosa (Cav.) Heimerl in Engler and Prantl., Lycium chilense Miers. ex Bertero, Chuquiraga hystrix Dom., L. divaricata, and Schinus johnstonii Barkley. Small shrubs were Atriplex lampa Gill. ex Mog., C. avellanedae Lorentz, Nassauvia fuegiana (Speg.) Cabrera. Nomenclature follows Correa (1971-1999). At all VUs, the sum of the cover of these species represented more than $85 \%$ of the total woody cover. We registered at each species the presence/absence of thorny stems and/or spiny leaves and collected fully expanded young to middle-aged green leaves (Bertiller et al. 2006) from three to nine randomly selected individuals at near, mid, and far subareas with respect to the watering point in November 2005. In five leaves per sampled individual, we assessed the leaf mass per area (LMA) by the procedure described in Bertiller et al. (2006). Other leaves of each plant were dried at $60^{\circ} \mathrm{C}$ for 48 hours and analyzed for nitrogen $(\mathrm{N})$ concentration by semimicro Kjeldahl (Schlesinger and Hasey 1981). Lignin was quantified by the Van Soest (1963) procedure and the concentration of total phenolic compounds by the FolinCiocalteu method using $50 \%$ methanol as extracting solution and tannic acid as standard (Waterman and Mole 1994).

We further calculated for each sampling site (three to six sites per VU) the relative contribution of each of the eight dominant shrub species to their total plant cover, and we used those values as weights to calculate the $\mathrm{VU}$ mean value of each shrub-leaf trait (LMA, lignin, $\mathrm{N}$, and phenolics) as:

$$
T_{t, i}=\left(\sum_{j=1}^{p} \sum_{k=1}^{s}{ }_{j} t_{k} w_{i, j, k}\right) / p
$$

Where $T$ is a weighed mean value of a shrub-leaf trait $t$ at $\mathrm{VU}_{i}, j$ is a sampled site of $\mathrm{VU}_{i}, k$ is a shrub-dominant species at site $j, 0<w_{i, j, k} \leq 1$ is the cover-based weight of species $k$ at the sampled site, $s$ is the total number of dominant shrub species at site $j$, and $p$ is the number of sampled sites of $\mathrm{VU}_{i}$. We also calculated the relative cover contribution of species with spiny leaves or thorny stems to the total woody plant cover at each sampled site and their mean cover values at each VU.

\section{Ewes' Visibility Range (EVR) at VUs}

We developed an EVR algorithm to assess the relative intricacy of VUs and the potential ability of sheep to acquire visual information across them. To this aim, we randomly selected four sampling sites of each VU across the paddock. At each site, we selected three sublocations and we obtained EVR estimations along eight horizontal sight-views equally spaced at $45^{\circ}$ azimuth intervals at ewes' head height $(0.7 \mathrm{~m})$ at each sublocation. Views were obtained with a $200-\mathrm{mm}$ (focal ratio: 3.5) Canon Fb optical telemeter (Canon Inc., Tokyo, Japan) and EVR was defined as the distance $(\mathrm{m})$ from the observer at which the focal plane showed $50 \%$ visual obstruction by vegetation (Boyd and Svejcar 2005). For each VU, we further obtained the average EVR (four sites $\times$ three sublocations $\times$ eight directions, $n=96$; Fig. 1 ). 
Ewes' Path Data and Selectivity upon VUs (Predictions 2 and 3) We obtained about 40000 records of positions (one each minute) of six ewes (weight range 35-39 kg) in April 2005 (ewes 1-2), September 2005 (ewes 3-5), and January 2006 (ewe 6), harnessed with standard Global Positioning System (GPS) receivers (e-Trex; Garmin, Olathe, KS) on their forebacks, while foraging at the selected paddock. The spatial accuracy of the GPS receivers was independently tested in simulated sheep trails and was found to be higher than the spatial resolution of the Landsat-7 image used to describe the field structure (data not shown). The two-strap harnesses also carried a solid-state memory and a programmable microcontroller (EEPROM-PIC16f84; Microchips Technology, Inc., Chandler, AR). The total weight of the harnessed system was $1.2 \mathrm{~kg}$, within the usual load range of telemetry equipment in studies of similar free-ranging mammals (Rutter et al. 1997; Hulbert et al. 1998). After being harnessed, the animals were first released in a small handling paddock among 125 other noninstrumented ewes, and their behavior was observed during a period (30 minutes) to check for signs of discomfort or nonacceptance of harnesses. We did not observe any of these, and all animals were released to the paddock. Recording of ewes' positions continued until battery charge was exhausted (usually 5-8 days). The collars were then recovered and the logged positions downloaded for analysis.

We converted the position estimates to digital vector files into an application for image handling (IDRISI v 14.02; Clark Labs) and overlaid them onto the image files of the classified Landsat-7 image of the area in order to cross-tabulate the frequency of visits $\left(f p_{i}\right)$ at each VU. The position data were further used to compute movement velocities $\left(\mathrm{m} \cdot \mathrm{min}^{-1}\right)$ between successive 1-minute records and velocity vector files were similarly overlaid onto the image files of the area for cross-tabulation analysis.

The selectivity $S_{i}$ exerted by sheep on a given $\mathrm{VU}_{i}$ was defined as the ratio:

$$
S_{i}=f p_{i} / p a_{i}
$$

where $f p_{i}$ is the frequency of positions of sheep on $\mathrm{VU}_{i}$ relative to all recorded positions and $p a_{i}$ is the number of image pixels classified as $\mathrm{VU}_{i}$ with respect to all image pixels of the paddock. Selectivity data of each VU were discriminated by subareas according to distances to the watering point (near, mid, far) and into two speeds: $0.5-$ $3 \mathrm{~m} \cdot \min ^{-1}$ (slow movement, grazing predominant) and $>3 \mathrm{~m} \cdot \min ^{-1}$ (fast movement, exploration predominant). We discarded selectivity values of periods of sustained immobility $\left(0 \mathrm{~m} \cdot \min ^{-1}\right)$ during more than 10 minutes, frequent at early afternoon and late night, which we assumed did not correspond to feeding activities.

\section{Statistical Analyses}

We used two-way analysis of variance (ANOVA) to analyze the significance of the differences in cover categories (total, tall shrubs, small shrubs, perennial grasses, perennial forbs, and annuals) among VUs at three distances (near, mid, and far) to the watering point, and eventual interactions between $\mathrm{VU}$ and distance. The assumptions of ANOVA were previously tested and data on tall shrubs and perennial grass cover were logarithmic-transformed to meet them. Multiple comparisons of cover categories among VUs were performed by LSD (least significant difference) test. Differences in structural and leaf chemical traits among shrub species and VUs were analyzed by one-way ANOVA and Kruskal-Wallis test, respectively. We used two-way ANOVA to analyze the significance of the differences in selectivity (S) by VUs (fixed factor) and ewe (random factor). Three-way ANOVA was used to assess the significance of the differences in (square-root transformed) $S$ by VUs, distance to the watering point, and speed (fixed factors). Interactions between factors were also tested. Pearson's correlation was used to analyze the relationship between structural and chemical shrub traits, and stepwise regression and Principal Component Analysis (PCA) were used to analyze the relationship between $S$ (all ewes together) of VUs and mean VU shrub-leaf traits, life form cover, and EVR. Principal component analysis was performed with the correlation matrix of the mean values of shrub-leaf traits, life form cover, EVR, and S of VUs. For ordination of VUs according to these traits, we further calculated the loading coefficients of each VU with respect to the two first principal components. All statistical analyses were performed with the package SPSS 7.5 (Norusis 1997).

\section{RESULTS}

\section{Characterization of the Heterogeneity of Vegetation Within the Paddock (Prediction 1)}

Vegetation Units and Patchiness. We identified six floristicphysiognomic vegetation units, which were patchily distributed across the paddock (Fig. 2A). VU6 was the least frequent and VU5 the most frequent on an area basis across the whole paddock (Fig. 2B). The least frequent VU6 was also the unit with the highest percentage of small patches (nominal radius lower than $20 \mathrm{~m}$ ) whereas the most frequent VU5 was mostly arranged in large patches (Figs. 2A and 2B; Table 1). VU5 and VU2 were highly frequent near the watering point. VU5 and VU3 dominated at mid distances to it, whereas VU2, VU3, VU4, and VU5 were all frequent at the far subarea. At all subareas VU1 and VU6 were rare. VU1 was the unit with the highest proportion of small patches at the subarea near to the watering point.

The VUs differed significantly in the total cover $\left(F_{5,25}=4.52\right.$, $P=0.013)$, and tall shrub $\left(F_{5,25}=7.19 ; P=0.002\right)$, small shrub $\left(F_{5,25}=10.37, P<0.001\right)$, perennial grass $\left(F_{5,25}=9.86\right.$, $P<0.001)$, and preferred plant $\left(F_{5,25}=12.48 ; P<0.001\right)$ covers (Fig. 3). The total cover was high at VU1, coinciding with the highest tall shrub, perennial grass, and total preferred plant cover, and the lowest small shrub cover. In contrast, the total cover was low at VU3 with minimum tall shrub, perennial grass, and total preferred plant cover, and the highest small shrub cover. The total, tall shrub, small shrub, perennial grass, and total preferred plant cover did not significantly $(P>0.05)$ differ among subareas at varying distance to the watering point (near, mid, far). We did not find significant interactions between the cover of life forms at VUs and the distance to the watering point. 
A

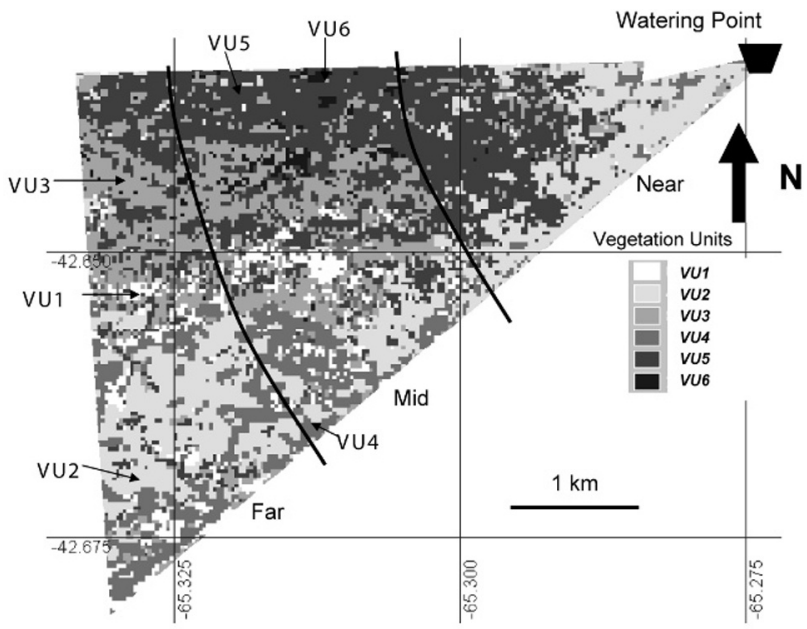

B
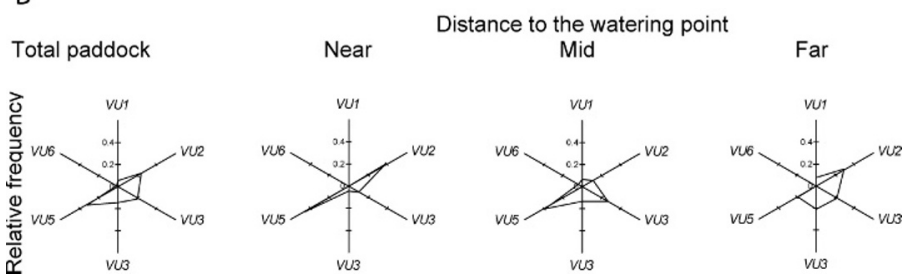

Figure 2. A, Graphical representation of the study paddock showing the spatial distribution of the six defined vegetation units (VU1 to VU6). The study paddock has a single watering point located at its northeastern corner. Curved lines delimit three subareas at varying distances to the watering point (near: 0-2500 m, mid: $2500-4500 \mathrm{~m}$, far: $>4500 \mathrm{~m}$ ). B, Polar plots showing the relative frequencies of the vegetation units (VU1 to VU6) at the total paddock and at the three delimited subareas according to their distance to the watering point (near, mid, far as in $\mathbf{A}$ ).

Structural and Chemical Characterization of Dominant Shrubs at VUs. The small shrub C. avellanedae and the tall shrub C. bystrix displayed high LMA values and low $\mathrm{N}$ concentration in green leaves (Table 2). We found low LMA and lignin concentration and high concentration of $\mathrm{N}$ in green leaves of the deciduous tall shrubs $L$. chilense and B. spinosa. The tall shrub S. johnstonii and the small shrub C. avellanedae had high lignin concentrations in green leaves. L. divaricata and $S$. johnstonii had high concentration of phenolics; low values of this trait were in L. chilense, C. hystrix (deciduous and evergreen tall shrubs, respectively), and the small shrub $A$. lampa. Thorny stems were frequent among tall shrubs, whereas leaves with spines were frequent among small shrubs. High

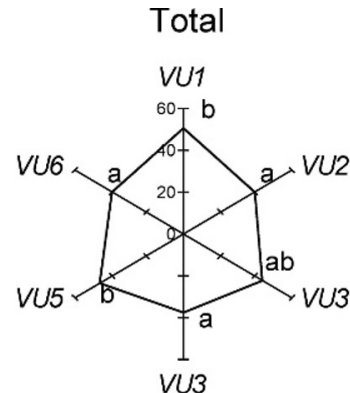<smiles>CC1(C)C2(C)C3(CCCCC3)C3(C)C1(C)C23C</smiles>

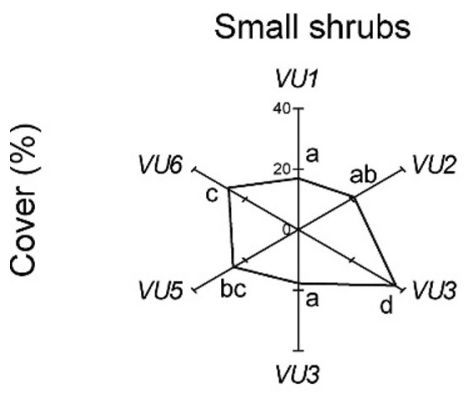

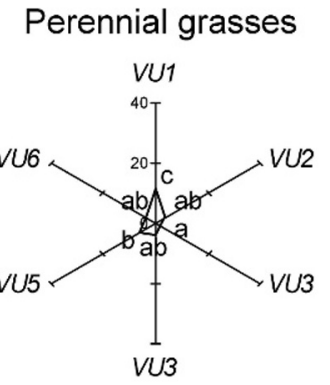

Total Preferred

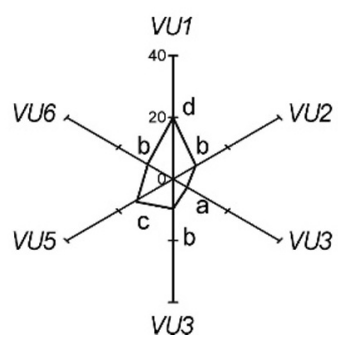

Figure 3. Polar plots showing the total, tall shrub, small shrub, perennial grass, and preferred plant cover (\%) at vegetation units (VU1 to VU6). Different lowercase letters indicate significant differences in cover categories among vegetation units.

LMA was related to low $\mathrm{N}$ concentration, high lignin concentration in green leaves, leaves with spines, and the absence of thorny stems (Table 3).

Mean shrub-leaf traits differed significantly among VUs (LMA: $F_{5,25}=5.16, P=0.004$; lignin: $F_{5,25}=5.04, P=0.004$ $\mathrm{N}: F_{5,25}=4.99, P=0.004$; phenolics: $F_{5,25}=3.81, P=0.015$; thorny stems: $F_{5,25}=9.64, P<0.001$; leaves with spines $F_{5,25}=6.17, P=0.001 ;$ Fig. 4$)$. VU3 showed the largest mean

Table 1. Number of patches and percentage of patches with nominal radius ( $r$ ) lower than the maximum visibility range (ca. $20 \mathrm{~m}$ ) per vegetation unit (VU) at the total paddock and at the three subareas (near, mid, and far) from the watering point.

\begin{tabular}{|c|c|c|c|c|c|c|c|c|}
\hline \multirow[b]{2}{*}{ VU } & \multicolumn{4}{|c|}{ No. of patches } & \multicolumn{4}{|c|}{ Percentage of patches with $r<20 \mathrm{~m}$} \\
\hline & Total & Near & Mid & Far & Total & Near & Mid & Far \\
\hline 1 & 180 & 9 & 92 & 79 & 43.8 & 66.6 & 46.7 & 37.9 \\
\hline 2 & 148 & 40 & 62 & 46 & 38.5 & 37.7 & 37.1 & 41.3 \\
\hline 3 & 301 & 99 & 120 & 82 & 38.5 & 41.4 & 42.5 & 29.3 \\
\hline 4 & 154 & 27 & 54 & 73 & 38.3 & 48.1 & 38.9 & 34.2 \\
\hline 5 & 218 & 28 & 84 & 106 & 36.2 & 42.8 & 38.1 & 33.0 \\
\hline 6 & 55 & 7 & 34 & 14 & 49.1 & 42.8 & 47.0 & 57.1 \\
\hline
\end{tabular}


Table 2. Mean $( \pm \mathrm{SE}$ ) physical and leaf chemical treats of the dominant shrubs at the study area. Different lowercase letters indicate significant differences in leaf traits among species. D indicates deciduous; E, evergreen; and LMA, leaf mass per area.

\begin{tabular}{|c|c|c|c|c|c|c|}
\hline Shrub life form/species & $\operatorname{LMA}\left(\mathrm{g} \cdot \mathrm{m}^{-2}\right)$ & N $(\%)$ & Lignin (\%) & Phenolics (\%) & $\begin{array}{l}\text { Thorny } \\
\text { stems }\end{array}$ & $\begin{array}{c}\text { Leaves } \\
\text { with spines }\end{array}$ \\
\hline \multicolumn{7}{|l|}{ Tall shrubs } \\
\hline Bougainvillea spinosa (D) & $107.2 \pm 7.6 \mathrm{~b}$ & $2.87 \pm 0.08 d$ & $5.78 \pm 0.42 a b$ & $2.81 \pm 0.12 b$ & $x$ & - \\
\hline Lycium chilense (D) & $67.3 \pm 6.0 \mathrm{a}$ & $2.69 \pm 0.09 d$ & $5.27 \pm 0.45 \mathrm{a}$ & $1.68 \pm 0.10 \mathrm{a}$ & $x$ & - \\
\hline Chuquiraga hystrix (E) & $318.1 \pm 11.4 f$ & $1.25 \pm 0.04 \mathrm{a}$ & $8.38 \pm 0.73 b$ & $1.57 \pm 0.18 \mathrm{a}$ & - & $x$ \\
\hline Larrea divaricata $(\mathrm{E})$ & $172.8 \pm 6.0 \mathrm{~d}$ & $1.97 \pm 0.04 \mathrm{c}$ & $4.98 \pm 0.32 \mathrm{a}$ & $15.15 \pm 0.50 d$ & - & - \\
\hline Schinus johnstonii (E) & $231.8 \pm 13.5 \mathrm{e}$ & $1.77 \pm 0.05 b c$ & $11.24 \pm 1.54 \mathrm{~d}$ & $16.56 \pm 0.14 d$ & $x$ & - \\
\hline \multicolumn{7}{|l|}{ Small shrubs } \\
\hline Atriplex lampa $(\mathrm{E})$ & $160.6 \pm 10.8 \mathrm{~cd}$ & $2.11 \pm 0.06 \mathrm{c}$ & $8.70 \pm 0.22 c$ & $1.29 \pm 0.08 \mathrm{a}$ & - & - \\
\hline Chuquiraga avellanedae (E) & $454.3 \pm 14.7 \mathrm{~g}$ & $1.29 \pm 0.03 \mathrm{a}$ & $10.80 \pm 0.93 \mathrm{~cd}$ & $3.28 \pm 0.11 b$ & - & $x$ \\
\hline Nassauvia fuegiana (E) & $133.8 \pm 19.8 \mathrm{bc}$ & $1.69 \pm 0.05 b$ & $6.99 \pm 0.24 b$ & $5.27 \pm 0.19 c$ & & $x$ \\
\hline
\end{tabular}

LMA and lignin concentration, and the lowest $\mathrm{N}$ and phenolics concentrations in green leaves of shrubs. This VU also showed the highest proportion of woody cover with spiny leaves and the lowest with thorny stems. The other VUs did not differ in the mean values of LMA and lignin concentration in green leaves of shrubs but in their values of $\mathrm{N}$ and phenolics. VU1 and VU2 showed high mean $\mathrm{N}$ concentration in green leaves of shrubs, and VU1 high concentration of phenolics and the highest proportion of woody cover with thorny stems.

\section{Ewes' Visibility Range (EVR) at VUs}

The mean EVR was maximum (over $20 \mathrm{~m}$ ) at VU3 with high values at VU5 and VU6 and low values at VU2 (9.6 m), VU1, and VU4 (Fig. 5). The cover of small shrubs was positively correlated to EVR $\left(r=0.765, F_{5,25}=16.92, P=0.001\right)$ and the cover of tall shrubs was negatively correlated to EVR $\left(r=-0.772, F_{5,25}=17.73, P=0.001\right)$.

\section{Ewes' Path Data and Selectivity Upon VUs (Predictions 2 and 3)} Ewes displayed a variety of paths differing in total length, localization within the paddock, and spatial spread of the visited locations (Fig. 6A). The paths of ewes 1-2 were mostly located at the northwest corner of the paddock, ewe 3 remained close to the watering point at the northeast area, and ewes 4-6 explored wide (but different) regions of the available paddock. There were no differences in $S$ among ewes $\left(F_{5,96}=0.86 ; P=0.522\right)$ nor significant interactions VU $\times$ ewe $\left(F_{25,96}=1.33 ; P=0.186\right)$, implying a lack of evidence of seasonal effects. The pattern of selectivity respect to VUs changed at varying distance to the watering point (Fig. 6B; significant interaction $\mathrm{VU} \times$ distance $F_{10,192}=3.77 ; P<0.001$ ) but it did not depend on the speed adopted by ewes to explore the VUs $\left(F_{1,192}=1.69 ; P=0.194\right)$. Near the watering point, $S$ did not significantly differ among VUs, whereas at mid and far distances ewes selected with higher frequency VU3, VU5, and VU6. At mid-distance to the watering point, VU5 and VU6 were similarly selected, whereas at far subareas VU5 was the most selected. We did not find significant $(P>0.05)$ interactions between speed and other factors (VUs or distance to the watering point).

The PCA (Fig. 7) clustered $S$ at mid and far distances to the watering point along with VU3 and VU6, and dominant structural characteristics of these, such as high EVR. This showed preferential ewes' selectivity for VU3 and VU6 with high EVR at those subareas. The proximity of VU5 to $S$ at all subareas in the PCA analysis indicated that ewes' selectivity for this $\mathrm{VU}$ is independent of the distance to the watering point. The PCA clustered S near the watering point along with VU1 and several of its dominant structural characteristics, such as high cover of perennial grasses and preferred plants. This pointed out increased ewes' selectivity for VU1 near to the watering point. VU2 and VU4 were clustered at low scores of PCA 2, unrelated to the previous groups indicating low ewes' selectivity for these VUs (Fig. 7).

The results of the multiple regression analysis also showed that traits explaining the variation in $S$ (all ewes together) varied depending on the distance to the watering point (Table 4). Near the watering point, the cover of perennial grasses was the single variable significantly explaining the highest fraction of the total variance in $S(11.1 \%)$. At mid and far distances to the watering point, both EVR (positively) and

Table 3. Pearson's correlations among leaf shrub traits (LMA indicates leaf mass per area; traits of green leaves include concentration of $\mathrm{N}$, lignin, and phenolics), thorny stems, and leaves with spines. Correlation significance level: ${ }^{*}=P \leq 0.05,{ }^{* *}=P \leq 0.01 ; n=66$.

\begin{tabular}{|c|c|c|c|c|c|c|}
\hline Traits & LMA & $\mathrm{N}$ & Lignin & Phenolics & Thorny stems & Leaves with spines \\
\hline LMA & 1.00 & $-0.80^{* *}$ & $0.67^{* *}$ & 0.05 & $-0.51^{\star \star}$ & $0.64^{\star \star}$ \\
\hline $\mathrm{N}$ & & 1.00 & $-0.55^{\star *}$ & -0.09 & $0.76^{\star \star}$ & $-0.78^{\star \star}$ \\
\hline Lignin & & & 1.00 & -0.13 & $-0.31^{\star}$ & $0.44^{\star}$ \\
\hline Phenolics & & & & 1.00 & -0.09 & -0.26 \\
\hline Thorny stems & & & & & 1.00 & $-0.57^{\star *}$ \\
\hline Leaves with spines & & & & & & 1.00 \\
\hline
\end{tabular}



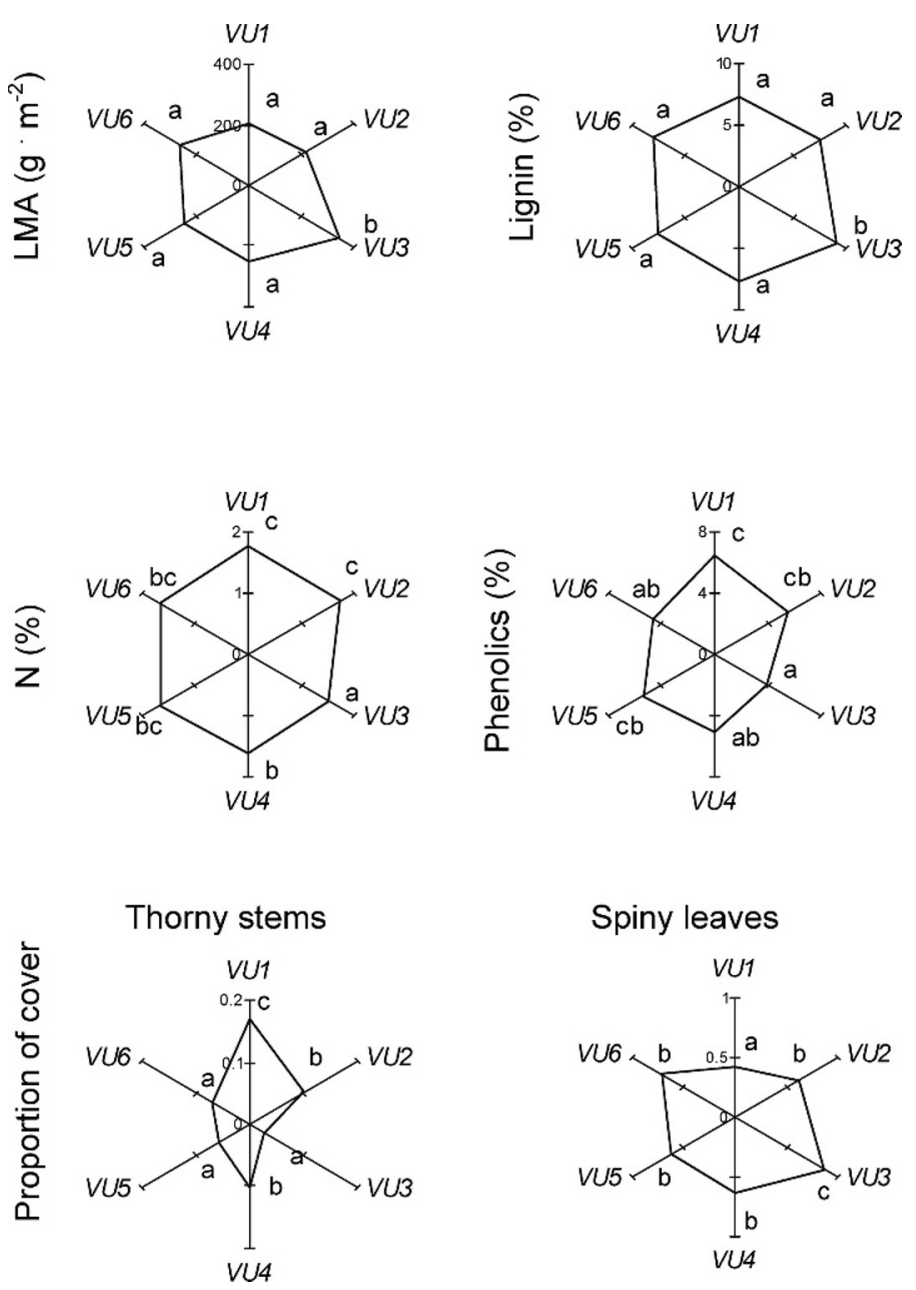

Figure 4. Polar plots showing mean values of structural and leaf chemical treats: LMA $\left(\mathrm{g} \cdot \mathrm{m}^{-2}\right), \mathrm{N}(\%)$, lignin $(\%)$, phenolics $(\%)$, and relative proportion of plant cover with thorny stems and spiny leaves cover at vegetation units (VU1 to VU6). Different lowercase letters indicate significant differences in traits among vegetation units. LMA indicates leaf mass per area.

mean lignin concentration in green leaves (negatively), along with the cover of tall shrubs (negatively) or small shrubs (positively), significantly explained $52.6 \%$ and $40.1 \%$, respectively, of the total variance in ewes' selectivity of VUs.

\section{DISCUSSION}

In accordance with our first prediction, the vegetation was spatially heterogeneous in terms of floristic-physiognomic vegetation units, visibility range, structural/chemical antiherbivore defenses, and cover of preferred plants within the grazing paddock and at subareas differing in their distance to the watering point. In this patchy environment, individual ewes used highly diverse paths, but irrespective of these, they all selected among a limited number of vegetation units. Primary selection was in terms of nonnutritional, structural/visual cues. This is consistent with our second prediction and with previous studies indicating the importance of nonnutritional traits in grazers' decisions (Fortin et al. 2003). Vegetation units with

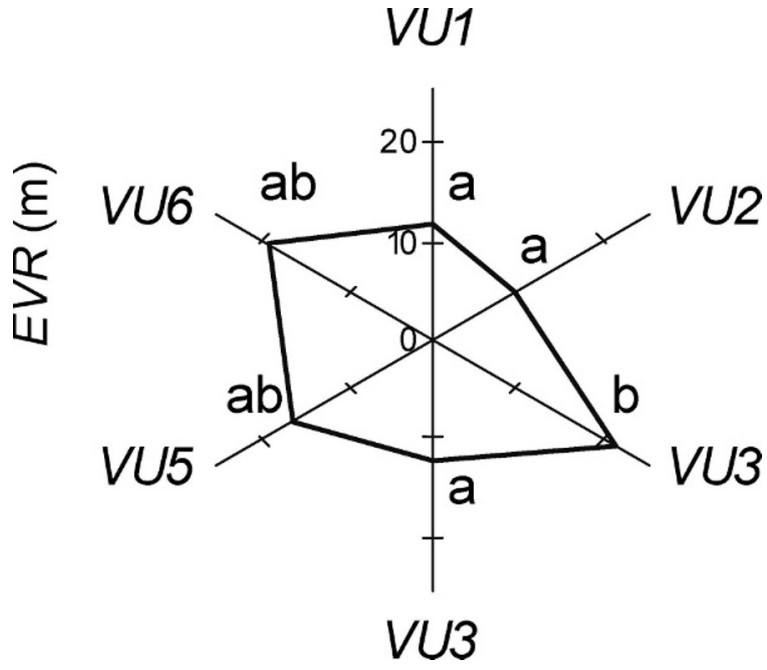

Figure 5. Mean ewes' visibility range (EVR, $m$ ) at vegetation units (VU1 to VU6). Different lowercase letters indicate significant differences in EVR among vegetation units.

low visual impairment and low levels of structural (thorny stems) plant antiherbivore defenses were primarily selected, irrespective of their relative offer of preferred plant cover or local abundance. The reasons for ewes preferring open vegetation units allowing wide visibility ranges are not clear at this point. It might be speculated that visibility would minimize the time and costs of traveling between feeding stations, which could be substantially high in visually-oriented grazers in shrubby rangelands (Gross et al. 1995). Avoiding visual impairment could also be related to maintaining adequate visual contact among congeners, orientation, search image forming, and predator risk avoidance (Jarman 1974; Berger 1978; Risenhoover and Bailey 1985; Penning et al. 1993; Molvar and Bowyer 1994; Dukas and Kamil 2001). These add further dimensions to views stressing the relevance of the biomass of available forage and the distance to a potentially preferred new neighbor patch as driving variables in grazers' spatial decisions (Noy-Meir 1973; Charnov 1976; Oom et al. 2004; Searle et al. 2006).

We also found that the nature of the structural cues related to visual impairment in the study paddock varied with the distance to the watering point. At subareas at mid and far distances to it, ewes selected vegetation units with low intricacy (high visibility range) resulting from high cover of small shrubs/ low cover of tall shrubs (VU3, VU5, and VU6). Near to the watering point, ewes also selected the low visibility unit VU1. At this area, this unit occurred mostly in small patches (diameters $<20 \mathrm{~m}$ ) that allow interpatch visibility in ranges comparable to those characteristic of intrapatch visibility at the less intricate vegetation units selected at mid and far distances to the watering point. Thus, ewes would profit from a visually open interpatch scenario, while accessing preferred species at the borders of VU1 patches.

In relation to our third prediction, sheep selected vegetation units with larger grazing rewards among those units with low visual impairment. This is consistent with other studies, indicating that predominant grazing options at small spatial scales are related to rewards and costs derived from grazing 

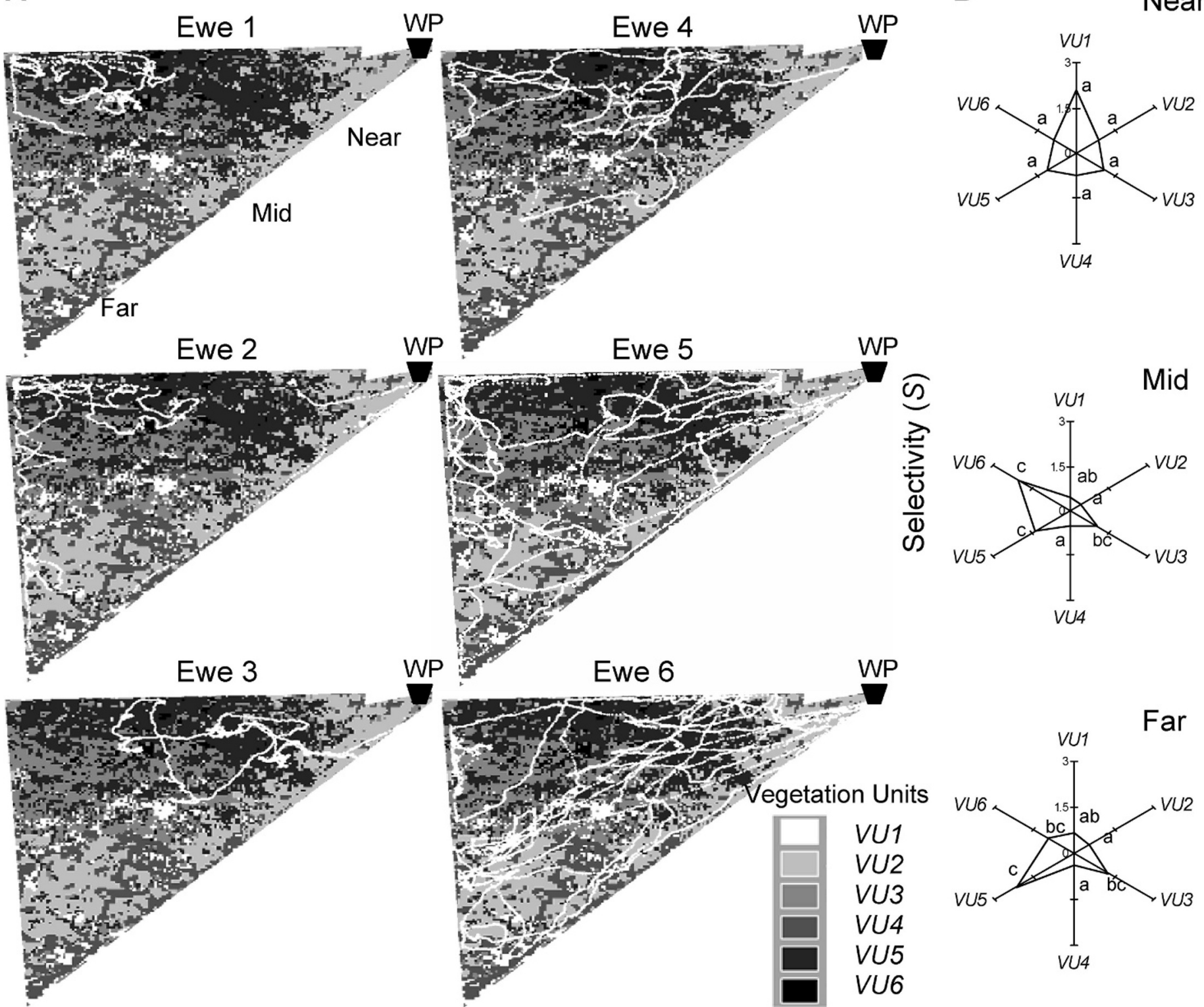

Figure 6. A, Graphical representations of the study paddock showing the paths of the six ewes. Ewes 1-2, April 2005; ewes 3-5, September 2005; ewe 6, January 2006. B, Polar graphs showing ewes' selectivity (S) upon vegetation units (VU1 to VU6) at the three distances to the watering point (WP): near $(0-2500 \mathrm{~m})$, mid $(2500-4500 \mathrm{~m})$, far (>4500 m). See also Fig. 2. Different lowercase letters indicate significant differences in traits among vegetation units.

efficiency on preferred plants of high forage quality (Oom et al. 2004; Searle et al. 2006). Also, we identified different grazingrelated rewards in relation to the distance to the watering point. High cover of small shrubs with low lignin represented grazingrelated rewards at mid and far distances to the watering point, along with low LMA in leaves and reduced physical antiherbivore defenses (absent or rare thorny stems) at VU5 or VU6. Near the watering point, grazing-related rewards included high cover of perennial grasses and preferred plants, and shrub leaves with high $\mathrm{N}$ concentration such as in VU1. These results indicate that vegetation selection oriented to maximize food quantity and quality, as predicted by classical foraging models (Senft et al. 1987) was in our study a necessary, but not overriding condition with respect to other nonnutritional foraging cues.

\section{CONCLUSIONS AND MANAGEMENT IMPLICATIONS}

Our results indicated that in the study paddock, sheep selectivity occurred in successive decision stages. These were related to visual impairment, antiherbivore physical/chemical defenses, and the offer of preferred plants. In a hierarchy of decisions, the abundance of preferred plants was not a sufficient condition for a high selection of vegetation units. Monitoring animal movements within shrubby paddocks of the Patagonian Monte with high visual impairment might supply criteria to assess the relevance of nonnutritional environmental traits on grazers' decisions. This information is valuable in identifying and predicting spots of potential land degradation, and planning the distribution of flocks within paddocks in the 


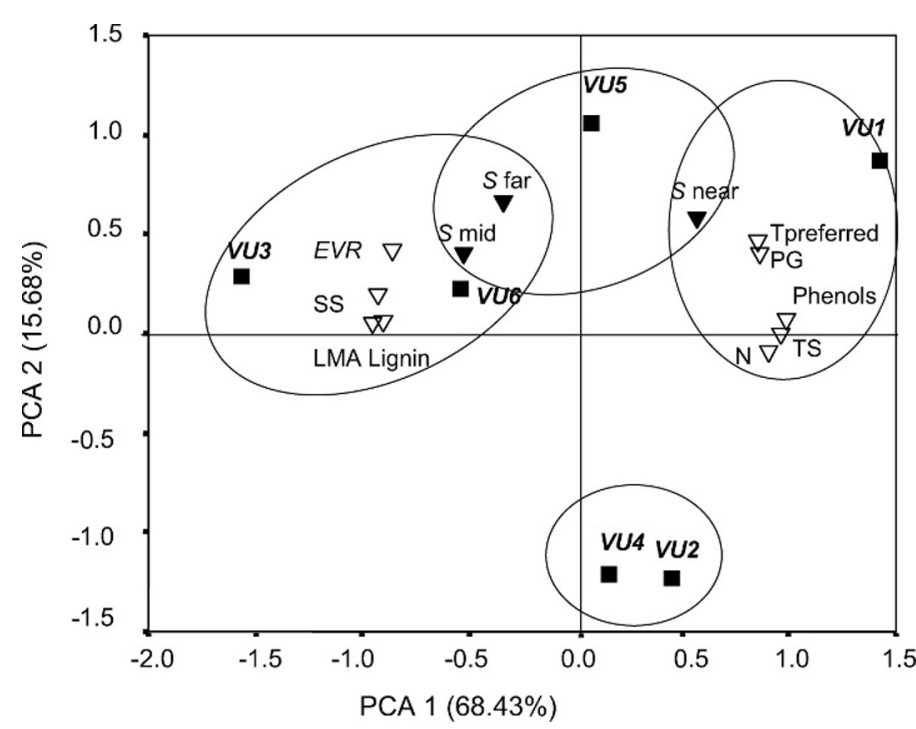

Figure 7. Ordination of plant structural (TS indicates tall shrubs; SS, small shrubs; PG, perennial grasses; and Tpreferred, total preferred covers) and leaf chemical attributes, ewes' visibility range (EVR), selectivity (S), and loading coefficients of vegetation units (VU1 to VU6) with respect to the two first principal components of the correlation matrix of mean plant structural and leaf chemical attributes, S, and EVR at all VUs. Ovals indicate closest affinity among plant traits, $S$, and VUs.

Table 4. Regression models between selectivity (dependent variable) and mean plant traits at the vegetation units (independent variables) at the three subareas (near, mid, and far) from the watering point $(n=72)$.

\begin{tabular}{|c|c|c|c|c|}
\hline Dependent variable & Independent variables & $R^{2}$ & $F$ & $P$ \\
\hline $\begin{array}{l}\text { Selectivity near to } \\
\text { the watering point }\end{array}$ & $\begin{array}{l}\text { Cover of perennial } \\
\text { grasses }\end{array}$ & 0.110 & 7.23 & $<0.01$ \\
\hline $\begin{array}{l}\text { Selectivity mid to } \\
\text { the watering point }\end{array}$ & $\begin{array}{l}\text { Visibility, lignin, } \\
\text { cover of tall shrubs }\end{array}$ & 0.526 & 25.19 & $<0.01$ \\
\hline $\begin{array}{l}\text { Selectivity far from } \\
\text { the watering point }\end{array}$ & $\begin{array}{l}\text { Visibility, lignin, } \\
\text { cover of small shrubs }\end{array}$ & 0.401 & 12.48 & $<0.01$ \\
\hline
\end{tabular}

context of sustainable management practices for shrubby rangelands.

\section{ACKNOWLEDGMENTS}

The National Commission for Space Activities supplied the Landsat-7 image. We appreciate Mr. N. Smit's cooperation and allowance to access his premises to perform the observations here reported. Claudia Sain performed the chemical analyses of plant tissues.

\section{LITERATURE CITED}

Adler, P. B., and S. A. Hall. 2005. The development of forage production and utilization gradients around livestock watering points. Landscape Ecology 20:319-333.

Adler, P. B., D. G. Mllchunas, O. E. Sala, I. C. Burke, and W. K. L. Lauenroth. 2005. Plant traits and ecosystem grazing effects: comparison of U.S. sagebrush steppe and Patagonian steppe. Ecological Applications 15:774-792.

Ares, J. 0., A. M. Beeskow, M. B. Bertiller, C. M. Rostagno, M. P. Irisarri, J. Anchorena, G. E. Defossé, and C. A. Merino. 1990. Structural and dynamic characteristics of overgrazed lands of northern Patagonia, Argentina. In: A. Breymeyer [ED.]. Managed grasslands. Amsterdam, The Netherlands: Elsevier Science. p. 268-274.

Ares, J. O., M. B. Bertiller, and A. J. Bisigato. 2003. Modeling and measurement of structural changes at a landscape scale in dryland areas. Ecological Modelling and Assessment 8:1-13.

Balley, D. W., J. E. Gross, E. A. Laca, L. R. Rittemhouse, M. B. Coughenour, and D. M. Swift. 1996. Mechanisms that result in large herbivore grazing distribution patterns. Journal of Range Management 49:386-400.

Balley, D. W., H. C. Vanwagoner, and R. Weinmeister. 2006. Individual animal selection has the potential to improve uniformity of grazing on foothill rangeland. Rangeland Ecology and Management 59:351-358.

Baldi, R., A. Pelliza-Sbriller, D. Elston, and S. Albon. 2004. High potential for competition between guanacos and sheep in Patagonia. Journal of Wildlife Management 68:924-938.

BARTA, Z. N., A. LIKER, AND F. Monus. 2004. The effects of predation risk on the use of social foraging tactics. Animal Behaviour 67:301-308.

Berger, J. 1978. Group size, foraging, and antipredator ploys: an analysis of bighorn sheep decisions. Behavioural Ecology and Sociobiology 4:91-99.

Bertiller, M. B., M. J. Mazzarino, A. L. Carrera, P. Diehl, P. Satti, M. Gobbi, and C. L. SAIN. 2006. Leaf strategies and soil $N$ across a regional humidity gradient in Patagonia. Oecologia 148:612-624.

Bisigato, A., And M. B. Bertiller, M. 1997. Grazing effects on patchy dryland vegetation in northern Patagonia. Journal of Arid Environments 36: 639-653.

Bisigato, A. J., M. B. Bertiller, J. 0. Ares, and G. 0. Pazos. 2005. Effect of grazing on plant patterns in arid ecosystems of Patagonian Monte. Ecography 28:561-572.

Boyd, C. S., and T. J. Svejcar. 2005. A visual obstruction technique for photo monitoring of willow clumps. Rangeland Ecology and Management 58:434-438.

Brown, J. S. 1970. Sheep behavior under unherded conditions on mountain summer ranges. Logan, UT, USA: Utah Agricultural Experiment Station as Journal Paper No. 1007. 14 p.

Charnov, E. L. 1976. Optimal foraging, the marginal value theorem. Theoretical Population Biology 9:129-136.

Correa, M. N. 1971-1999. Flora Patagónica. Buenos Aires, Argentina: Colección Científica del INTA. Volume I. 391 p. Volume II. 219 p. Volume III. 563 p. Volume IV. 868 p. Volume V. 381 p. Volume VI. 536 p. Volume VII. 451 p.

DuKAS, R., AND A. C. KamIL. 2001. Limited attention: the constraint underlying search image. Behavioural Ecolology 12:192-199.

ForTIN, D. 2002. Optimal searching behaviour: the value of sampling information. Ecological Modelling 153:279-290.

Fortin, D., J. M. Fryxell, L. O’Brodovich, and D. Frandsen. 2003. Foraging ecology of bison at the landscape and plant community levels: the applicability of energy maximization principles. Oecologia 134:219-227.

Fortin, D., J. M. Fryxell, and R. Pilote. 2002. The temporal scale of foraging decisions in bison. Ecology 83:970-982.

FryXeLL, J. M., AND C. M. Doucet. 1993. Diet choice and the functional response of beavers. Ecology 74:1297-1306.

Ganskopp, D., AND D. BohneRt. 2006. Do pasture-scale nutritional patterns affect cattle distribution on rangelands? Rangelands Ecology and Management 59:189-196

Graetz, R. D., And J. A. LudWIG. 1978. A method for the analysis of biosphere data applicable to range assessment. The Australian Rangeland Journal 1:126136.

Gross, J. E., C. Zank, T. Hobbs, and D. E. Spalinger. 1995. Movement rules for herbivores in spatially heterogeneous environments: responses to small scale pattern. Landscape Ecology 4:209-217.

Hulbert, I. A. R., J. T. B. Wyllie, A. Waterhouse, J. French, and D. McNulty. 1998. A note on the circadian rhythm and feeding behavior of sheep fitted with a lightweight GPS collar. Applied Animal Behaviour Science 60:359364.

Jarman, P. J. 1974. The social organisation of antelope in relation to their ecology. Behaviour 48:215-267. 
Jeltsch, F., S. J. Milton, W. R. J. Dean, and N. van Roogen. 1997. Simulated pattern formation around artificial waterholes in the semi-arid Kalahari. Journal of Vegetation Science 8:177-188.

Judson, O. P. 1994. The rise of the individual-based model in ecology. Trends in Ecology and Evolution 9:9-14.

Launchbaugh, K., AND L. D. Howery. 2005. Understanding landscape use patterns of livestock as a consequence of foraging behaviour. Rangeland Ecology and Management 58:99-108.

LAUENROTH, W. K. 1998. Guanacos, spiny shrubs and the evolutionary history of grazing in the Patagonian steppe. Ecología Austral 8:211-215.

León, R. J. C., D. Bran, M. Collantes, J. M. Paruelo, and A. Soriano. 1998. Grandes unidades de la Patagonia extra andina. Ecología Austral 8:125-144.

Molvar, E. M., AND R. T. Bowyer. 1994. Costs and benefits of group living in a recently social ungulate, the Alaskan moose. Journal of Mammalogy 75:621-630.

Morghan, K. J. R., R. L. Sheley, and T. J. Svejcar. 2006. Successful adaptive management-the integration of research and management. Rangeland Ecology and Management 59:216-219.

NoRUsIs, M. J. 1977. SPSS Advanced statistics 7.5. Chicago, IL: SPSS. p. 1-179.

Noy-MelR, E. 1973. Desert ecosystems: environment and producers. Annual Review of Ecology and Systematics 4:5-52.

Oom, S. P., J. A. Beecham, C. J. Legg, and A. J. Hester. 2004. Foraging in a complex environment: from foraging strategies to emergent spatial properties. Ecological Complexity 1:299-327.

OWen-Smith, N., And P. Novellie. 1982. What should a clever ungulate eat? American Naturalist 119:151-178.

Penning, P. D., A. J. Parsons, J. A. Newman, R. J. Orr, and A. Harvey. 1993. The effects of group size on grazing time in sheep. Applied Animal Behaviour Science 37:101-109.

RichaRDS, J. A. 1986. Remote sensing digital image analysis: an introduction. Berlin, Germany: Springer. 439 p.

Risenhoover, K., AND J. A. BAlley. 1985. Relationships between group size, feeding time, and agonistic behavior of mountain goats. Canadian Journal of Zoology 63:2501-2506.
Rutter, S. M., N. A. Beresford, and G. Roberts. 1997. Use of GPS to identify the grazing areas of hill sheep. Computers and Electronics in Agriculture 17:177-188.

Schlesinger, W. H., and M. M. Hasey. 1981. Decomposition on chaparral shrubs foliage: losses of organic and inorganic constituents from deciduous and evergreen leaves. Ecology 62:762-774.

Searle, K. R., T. Vandervelde, L. Thompson Hobbs, L. A. Shipley, and B. A. Wunder. 2006. Spatial context influences patch residence time in foraging herbivores. Oecologia 148:710-719.

Senft, R. L., M. B. Coughenour, D. W. Balley, L. R. Rittenhouse, O. E. Sala, and D. M. SwIFt. 1987. Large herbivore foraging and ecological hierarchies. Bioscience 37:789-799.

Skarpe, C., I. Jansson, L. Seljel, R. Bergström, and E. Roskaft. 2007. Browsing by goats on three spatial scales in a semi-arid savanna. Journal of Arid Environments 68:480-491.

Somlo, R. 1997. Atlas dietario de herbívoros patagónicos. Bariloche, Argentina: PRODESAR-INTA-GTZ. $109 \mathrm{p}$.

Stephens, D. W., and J. R. KreBs. 1986. Foraging theory. Princeton, NJ, USA: Princeton University Press. 247 p.

Van Soest, P. J. 1963. Use of detergents in the analysis of fibrous feeds II. A rapid method for the determination of fiber and lignin. Journal of Association of Official Analytical Chemists 46:830-835.

Viswanathan, G. M., S. V. Buldrrev, S. Havlin, M. G. E. da Luz, E. P. Raposo, and H. E. Stanley. 1999. Optimizing the success of random searches. Nature 401:911-914.

WallisDevries, M. E., E. A. Laca, and M. W. Demment. 1999. The importance of scale of patchiness for selectivity in grazing herbivores. Oecologia 121:355-363.

Waterman, P. G., and S. Mole. 1994. Extraction and chemical quantification. In: Analysis of phenolics plant metabolites. Oxford, United Kingdom: Blackwell Scientific Publications. p. 66-103.

Zollner, P. A., and S. L. Lima. 1999. Search strategies for landscape-level interpatch movement. Ecology 80:1019-1030. 